\title{
DYNAMIC PROPERTIES MODELING OF THE THERMOELECTRIC FIRE SENSORS IN THE AIRCRAFT FIRE SUPPRESSION SYSTEM
}

\section{MODELOWANIE DYNAMICZNYCH WLAŚCIWOŚCI TERMOELEKTRYCZNYCH CZUJNIKÓW POŻARU W LOTNICZYM SYSTEMIE PRZECIWPOŻAROWYM}

\author{
Andrzej Szelmanowski, Mariusz Zieja, Krzysztof Głyda
}

Air Force Institute of Technology, Instutut Techniczny Wojsk Lotniczych

\begin{abstract}
The paper presents selected results of work at the Air Force Institute of Technology (AFIT) in the concerning modeling the dynamic properties of fire detectors used in aviation fire protection systems. In order to determine the conditions of false fire signals, the simulation models of thermoelectric fire detectors have been developed. Simulation models were tested in Matlab-Simulink computational packages for various methods of heating and cooling the sensors (among others, changes in ambient air temperature of the sensor, caused by the EWU exhaust gas diffusers were simulated - these diffusers are used to distribute flue gases from helicopter engines).
\end{abstract}

Keywords: aircraft fire suppression systems, research methods

Streszczenie: $W$ artykule przedstawiono wybrane wyniki prac realizowanych $w$ Instytucie Technicznym Wojsk Lotniczych (ITWL) w zakresie modelowania dynamicznych właściwości termoelektrycznych czujników pożaru stosowanych w lotniczych systemach przeciwpożarowych. Dla określania warunków fatszywego sygnalizowania pożaru opracowano modele symulacyjne dziatania termoelektrycznych czujników pożaru. Badania modeli symulacyjnych wykonano w pakietach obliczeniowych Matlab-Simulink dla różnych sposobów nagrzewania i chłodzenia czujników (m.in. symulowano zmiany temperatury powietrza otoczenia czujnika wywolane wykorzystaniem rozpraszaczy gazów wylotowych EWU, używanych do rozprowadzania spalin pochodzacych od silników śmigłowca).

Stowa kluczowe: lotnicze systemy przeciwpożarowe, metody badań 
Dynamic properties modeling of the thermoelectric fire sensors in the aircraft... Modelowanie dynamicznych właściwości termoelektrycznych czujników pożaru...

\section{Wstęp}

Genezą podjętych w ITWL badań lotniczych systemów przeciwpożarowych były liczne przypadki ich fałszywego zadziałania $[4,6,7]$. Zdarzenia te bezpośrednio zagrażały bezpieczeństwu lotu, zmuszając załogę do bezzwłocznego lądowania w terenie przygodnym. Szczególne zagrożenie występowało w czasie realizacji misji wojskowych w PKW Irak i Afganistan, gdzie przygodne lądowanie wiązało się $\mathrm{z}$ możliwością wykrycia i ostrzału śmigłowca przez nieprzyjaciela. Jednym z lotniczych systemów przeciwpożarowych eksploatowanych m.in. na samolotach An-28 oraz śmigłowcach $z$ rodziny $\mathrm{W}-3 / 3 \mathrm{~W} / 3 \mathrm{WA} / 3 \mathrm{PL}$ i Mi/8/14/17/24 jest system SSP-FK, wykorzystujący termoelektryczne czujniki pożaru DPS i DTBG $[1,2]$. Jak wykazały wyniki analiz niesprawności systemu SSP-FK wykonane w ITWL [3], udział przypadków fałszywego zadziałania tego systemu wynosi około 67\%, zaś udział czujników DPS i DTBG wynosi około 18\% (rys. 1).
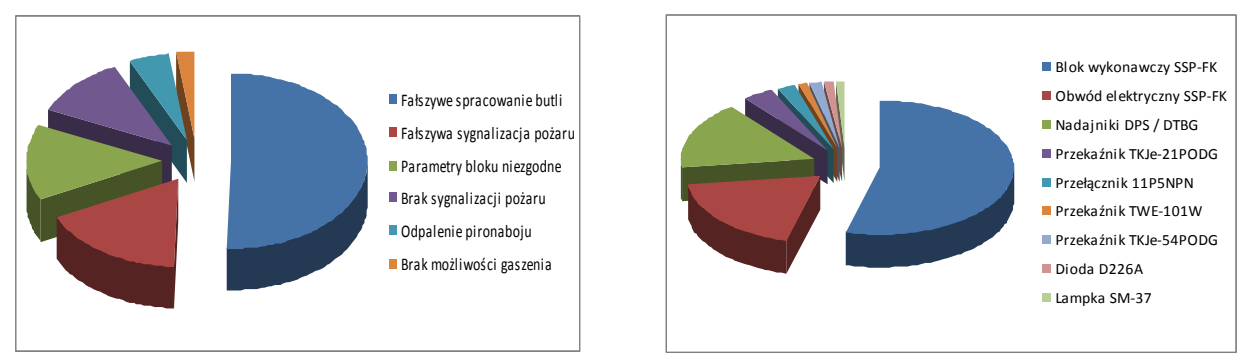

Rys. 1 Udział przypadków fatszywego zadziałania w niesprawnościach systemu SSP-FK (po lewej) oraz udziat w nich czujników pożaru DPS i DTBG (po prawej) [3]

Przykładem takiego zdarzenia, było samoczynne zadziałanie lotniczego systemu przeciwpożarowego SSP-FK, włącznie $\mathrm{z}$ uruchomieniem butli gaśniczych na śmigłowcu Mi-8 w dniu 27.01.2014 r. w JW Dęblin (rys. 2).
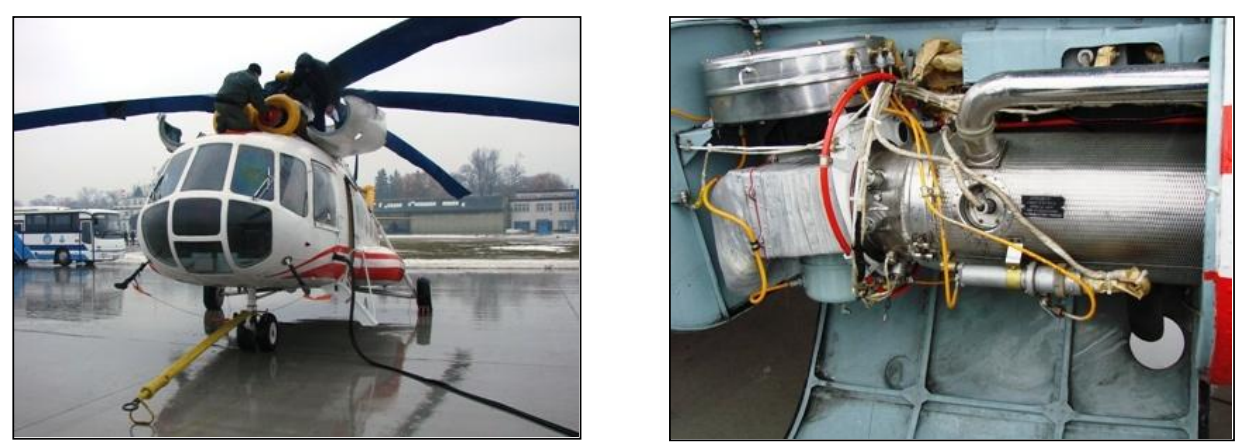

Rys. 2 Widok śmigłowca Mi-8 (po lewej) oraz przedziatu pieca ogrzewczego KO-50 dozorowanego przez system SSP-FK (po prawej) [7] 
Rozwiązanie problemów z fałszywą sygnalizacją pożaru systemu SSP-FK jest zagadnieniem bardzo ważnym dla bezpiecznej eksploatacji samolotów i śmigłowców wojskowych [4, 6], gdyż jest on systemem prewencyjnym (ostrzegającym załogę o możliwości wystąpienia pożaru) i ratowniczym (mającym ugasić pożar) w każdej fazie ich lotu. Jednym z problemów, które wystąpiły w badaniach termoelektrycznych czujników pożaru DPS i DTBG (stosowanych m.in. w systemach SSP-FK) było oszacowanie charakteru przebiegu sygnału podczas dynamicznych zmian ogrzewania czujnika (a szczególnie wartości maksymalnej sygnału i czasu jej trwania), mającego bezpośredni wpływ na uruchomienie układu sygnalizacji pożaru podczas wystąpienia tzw. sygnału podprogowego, uruchamiającego system przy obniżonym napięciu zasilania [3]. Problem ten jest bardzo istotny, gdyż podczas włączenia do pracy urządzeń i instalacji elektrycznych o dużym poborze prądu (np. w czasie uruchamiania silników śmigłowca), powstają chwilowe zaburzenia napięcia zasilania z sieci pokładowej [5].

Na podstawie analizy działania systemu przeciwpożarowego SSP-FK oraz badań wykonanych na pokładzie śmigłowca Mi-8 jako jedną z możliwych przyczyn jego samoczynnego zadziałania przyjęto hipotezę generacji napięcia uruchamiającego w czujnikach DPS na skutek gwałtownych zmian temperatury otoczenia w dozorowanym przedziale (m.in. oddziaływanie mrozu, podmuch zimnego lub gorącego powietrza). W celu weryfikacji powyższej hipotezy wykonano odpowiednie symulacje komputerowe, a ich wyniki zweryfikowano w warunkach laboratoryjnych [7].

\section{Opis działania termoelektrycznych czujników pożaru DPS i DTBG}

Działanie systemu przeciwpożarowego SSP-FK z termoelektrycznymi czujnikami pożaru DPS lub DTBG polega na wykryciu ogniska pożaru w dozorowanych strefach na pokładzie śmigłowca oraz jego sygnalizacji (uruchomienie układu gaśniczego jest tylko w trybie automatycznym). Na pokładzie śmigłowca Mi-8 system SSP-FK działa w taki sposób, że czujniki pożaru wytwarzają siłę termoelektryczną, której wielkość jest proporcjonalna do różnicy pomiędzy temperaturą spoin odkrytych termoelementu czujnika (nagrzewanych lub chłodzonych powietrzem otoczenia w dozorowanym przedziale śmigłowca), a temperaturą zakrytych spoin umieszczonych w złączu czujnika. W blokach wykonawczych SSP-FK-BI podawana z czujników pożaru siła termoelektryczna porównywana jest $\mathrm{z}$ dopuszczalnym poziomem napięcia odniesienia i w przypadku przekroczenia tej wartości na wyjściu bloku wykonawczego pojawia się sygnał uruchamiający układy sygnalizacji i gaszenia pożaru $[1,2]$.

\section{Opis i zasada funkcjonowania czujników typu DPS}

Termoelektryczne czujniki pożaru DPS (rys. 3) są typowym rozwiązaniem wykorzystującym architekturę $\mathrm{z}$ pojedynczym układem spoin odkrytych, osłonionych mechanicznie, oraz spoin zakrytych, umieszczonych w złączu. Sygnał napięciowy otrzymywany z czujnika DPS jest wypadkową sił termoelektrycznych generowanych w spoinach odkrytych i zakrytych. 
Dynamic properties modeling of the thermoelectric fire sensors in the aircraft... Modelowanie dynamicznych właściwości termoelektrycznych czujników pożaru...
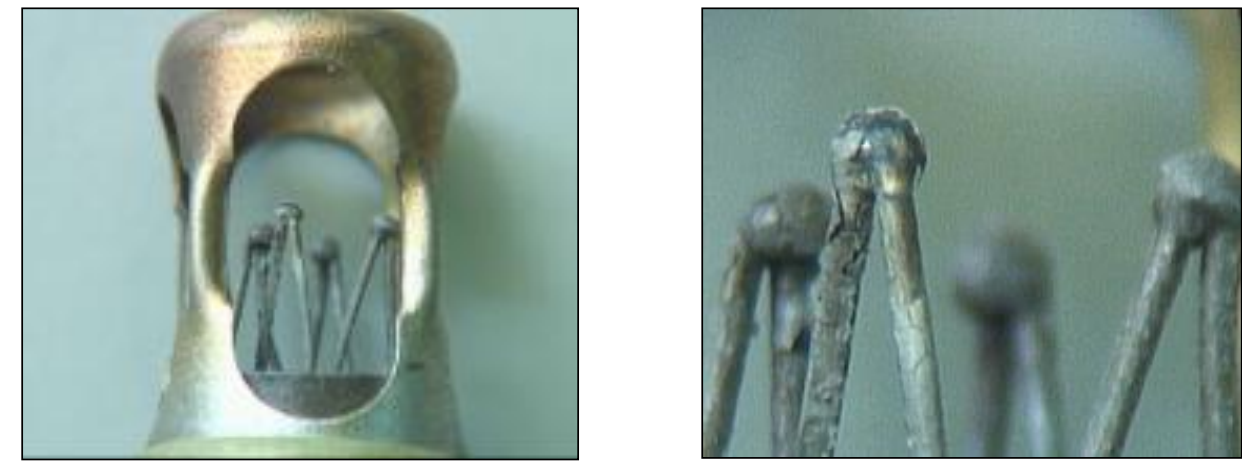

Rys. 3 Widok budowy czujnika DPS (po lewej) i jego spoin odkrytych (po prawej) [7]

\section{Opis i zasada funkcjonowania czujników typu DTBG}

Termoelektryczne czujniki pożaru DTBG (rys. 4) posiadają podwójny układ spoin: spoiny dolne (grubsze) tzw. I korony, oraz spoiny górne (drobniejsze) tzw. II korony, szybciej przyjmujące i oddające ciepło. Sygnał napięciowy otrzymywany $\mathrm{z}$ czujnika DTBG jest wypadkową sił termoelektrycznych generowanych w poszczególnych koronach spoin.
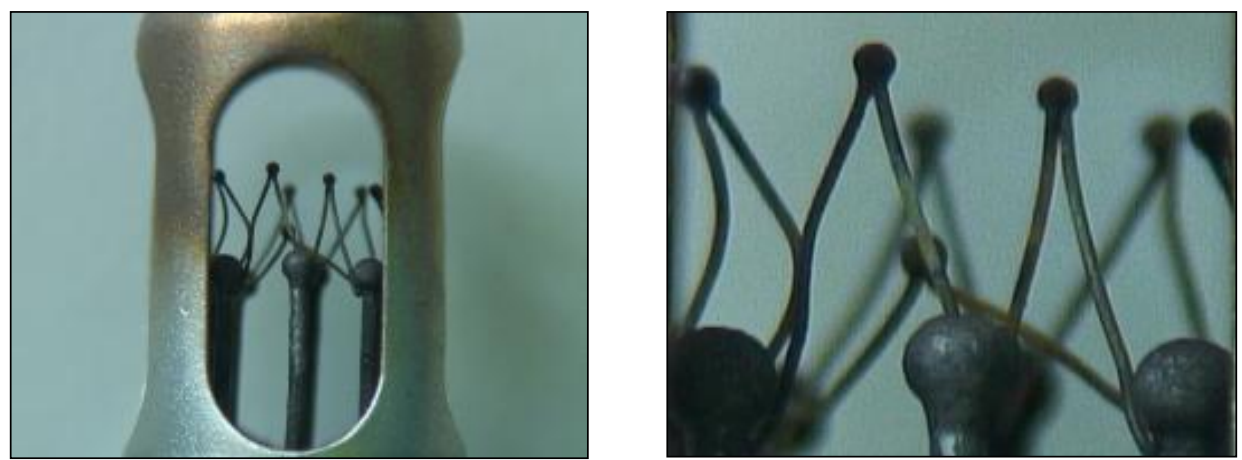

Rys. 4 Widok budowy czujnika DTBG (po lewej) i jego spoin odkrytych (po prawej) [7]

\section{Podstawy modelowania termoelektrycznych czujników pożaru}

$\mathrm{Na}$ podstawie analizy i badań wstępnych czujników pożaru DPS i DTBG opracowano modele symulacyjne działania ich elementów termicznych. Przyjęto, że na obecnym etapie teoretycznych badań tego systemu do modelowania działania termoelektrycznych czujników pożaru DPS i DTBG wystarczy uwzględnienie stałych czasowych charakteryzujących opóźnienia w nagrzewaniu i chłodzeniu spoin odkrytych i zakrytych w złączu czujnika.

Analiza połączeń elektrycznych między spoinami odkrytymi (rys. 5) umożliwiła określenie powiązań między spoinami w obszarze detekcji. 

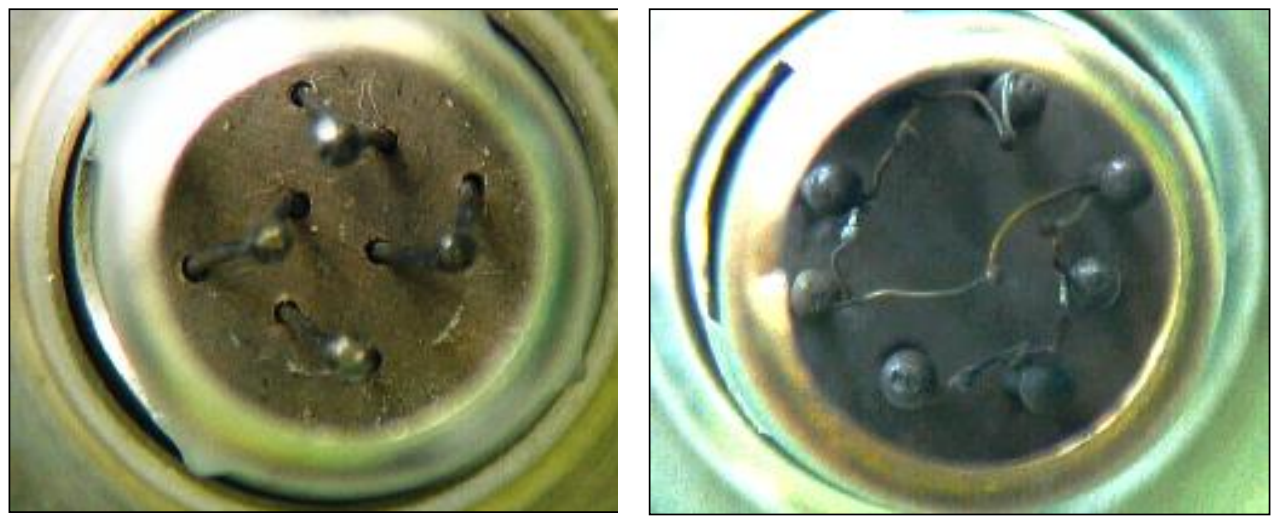

Rys. 5 Widok spoin odkrytych w czujniku DPS (po lewej) i DTBG (po prawej) [7]

Z kolei analiza budowy wewnętrznej złącza czujnika ze spoinami zakrytymi (rys. 6) umożliwiła określenie powiązań między spoinami w złączu.
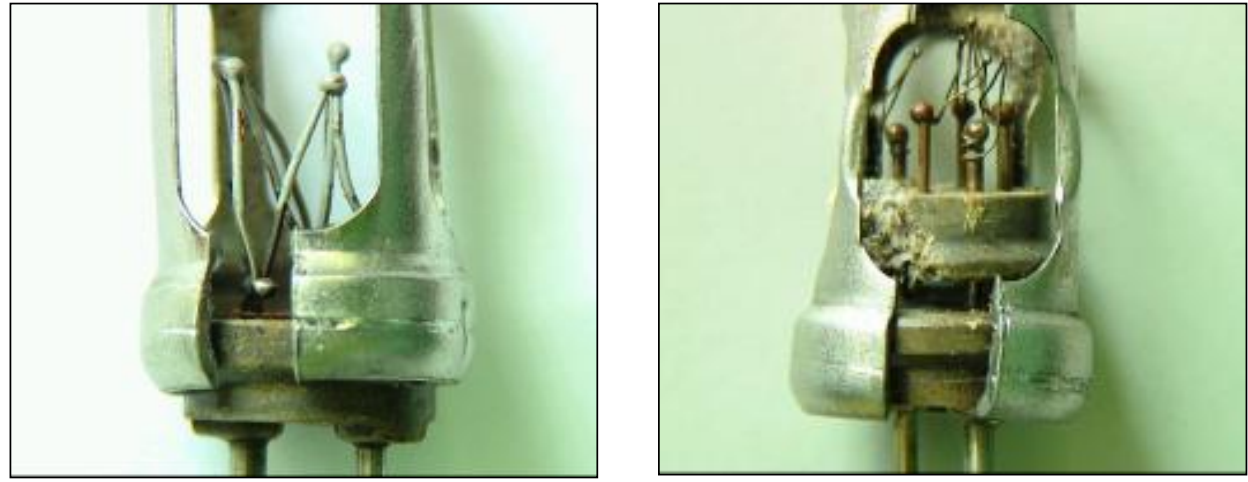

Rys. 6 Widok spoin zakrytych w czujniku DPS (po lewej) i DTBG (po prawej) [7]

Przeprowadzone badania strukturalne pozwoliły na sformułowanie opisu i opracowanie modelu matematycznego działania czujników DPS i DTBG.

\section{Opis modelu matematycznego czujników typu DPS}

Pełny opis modelu matematycznego działania termoelektrycznego czujnika pożaru typu DPS wymaga analizy chwilowych rozkładów temperatury poszczególnych spoin odkrytych i zakrytych w złączu (oraz przewodów elektrycznych i materiałów izolacyjnych łączących spoiny wewnątrz złącza) z wykorzystaniem równań przewodnictwa cieplnego, uwzględniających opóźnienia w nagrzewaniu i chłodzeniu spoin (rys. 7). 
Dynamic properties modeling of the thermoelectric fire sensors in the aircraft... Modelowanie dynamicznych właściwości termoelektrycznych czujników pożaru...

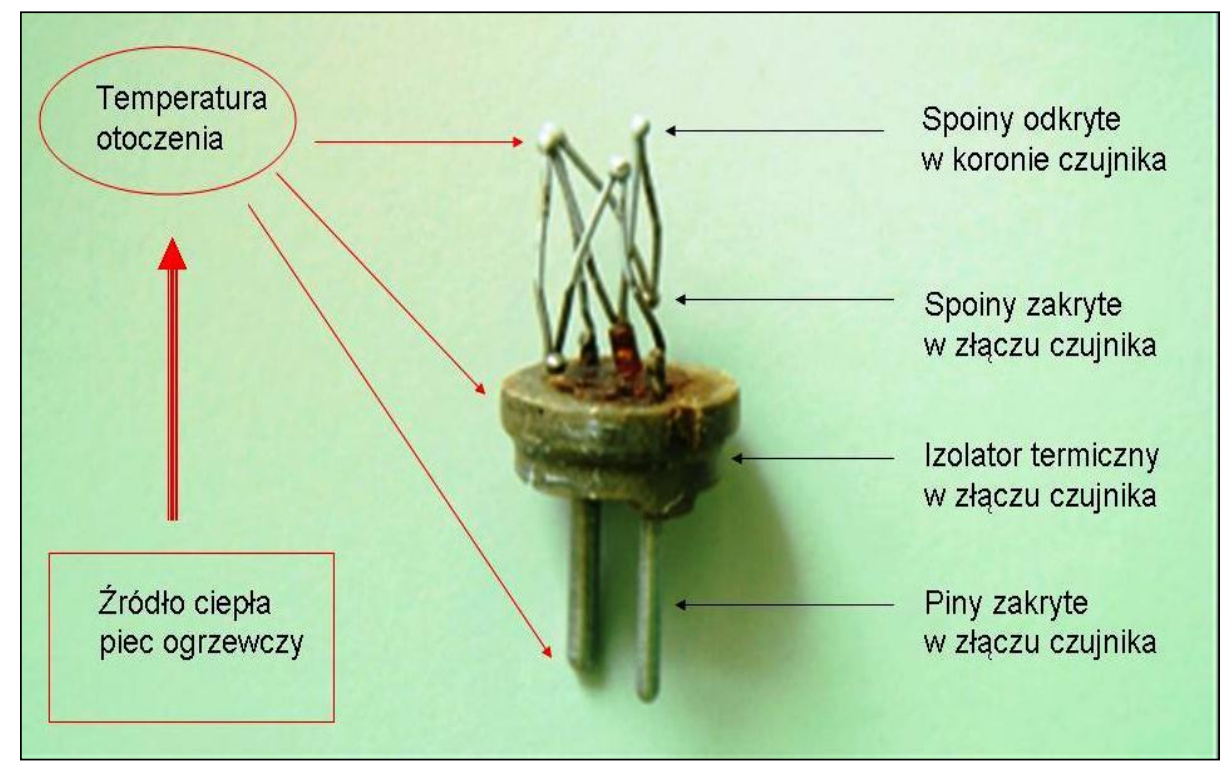

Rys. 7 Opis elementów pomiarowych i sygnałowych dla czujnika DPS [7]

Uproszczony model matematyczny opisujący działanie termoelektrycznego czujnika pożaru DPS, z jedną koroną spoin odkrytych, można przedstawić przy wykorzystaniu zależności:

$$
U_{D P S}(s)=\left\{K_{D P S}\left[\frac{1}{\tau_{S O} \cdot s+1} \cdot T_{\text {OTOCZ }}(s)-\frac{1}{\tau_{S Z} \cdot s+1} \cdot T_{Z L A C Z A}(s)\right]\right\}
$$

gdzie:

$U_{D P S}(s)$ - transformata operatorowa Laplace'a siły termoelektrycznej generowanej w czujniku DPS z pojedynczą koroną spoin;

$K_{D P S} \quad-$ współczynnik skalowania czujnika DPS;

$T_{\text {отосZ }}(s)$ - transformata operatorowa Laplace'a temperatury powietrza otaczającego czujnik DPS i oddziałującego bezpośrednio na spoiny odkryte poprzez ich nagrzewanie lub chłodzenie;

$T_{Z L A C Z A}(s)$ - transformata operatorowa Laplace'a temperatury złącza elektrycznego czujnika DPS i oddziałującego pośrednio na spoiny zakryte i opóźniającego ich nagrzewanie lub chłodzenie;

$\tau_{S O} \quad-$ stała czasowa spoin odkrytych;

$\tau_{S Z} \quad-$ stała czasowa spoin zakrytych (zabudowanych w złączu). 
Model ten umożliwia m.in. badania wpływu opóźnień w nagrzewaniu i chłodzeniu poszczególnych spoin czujnika DPS na wartość i przebieg maksymalnej siły termoelektrycznej w nim generowanej.

Wyniki takich badań pozwalają ocenić możliwości generacji sygnału podprogowego z czujnika, powodującego fałszywe zadziałanie i uruchomienie systemu przeciwpożarowego SSP-FK przy obniżonym napięciu zasilania.

\section{Opis modelu matematycznego czujników typu DTBG}

Podobnie jak dla czujnika DPS, pełny opis modelu matematycznego działania termoelektrycznego czujnika pożaru typu DTBG wymaga analizy chwilowych rozkładów temperatury poszczególnych spoin $\mathrm{z}$ wykorzystaniem równań przewodnictwa cieplnego. Jego złożoność komplikują dodatkowo różne wartości opóźnień spoin odkrytych I i II korony (rys. 8), mające wpływ na generowaną siłę termoelektryczną $\mathrm{w}$ złożonych stanach dynamicznych np. podczas chwilowego schłodzenia, a następnie ogrzania czujnika z rozpraszaczy gazów wylotowych EWU [1].

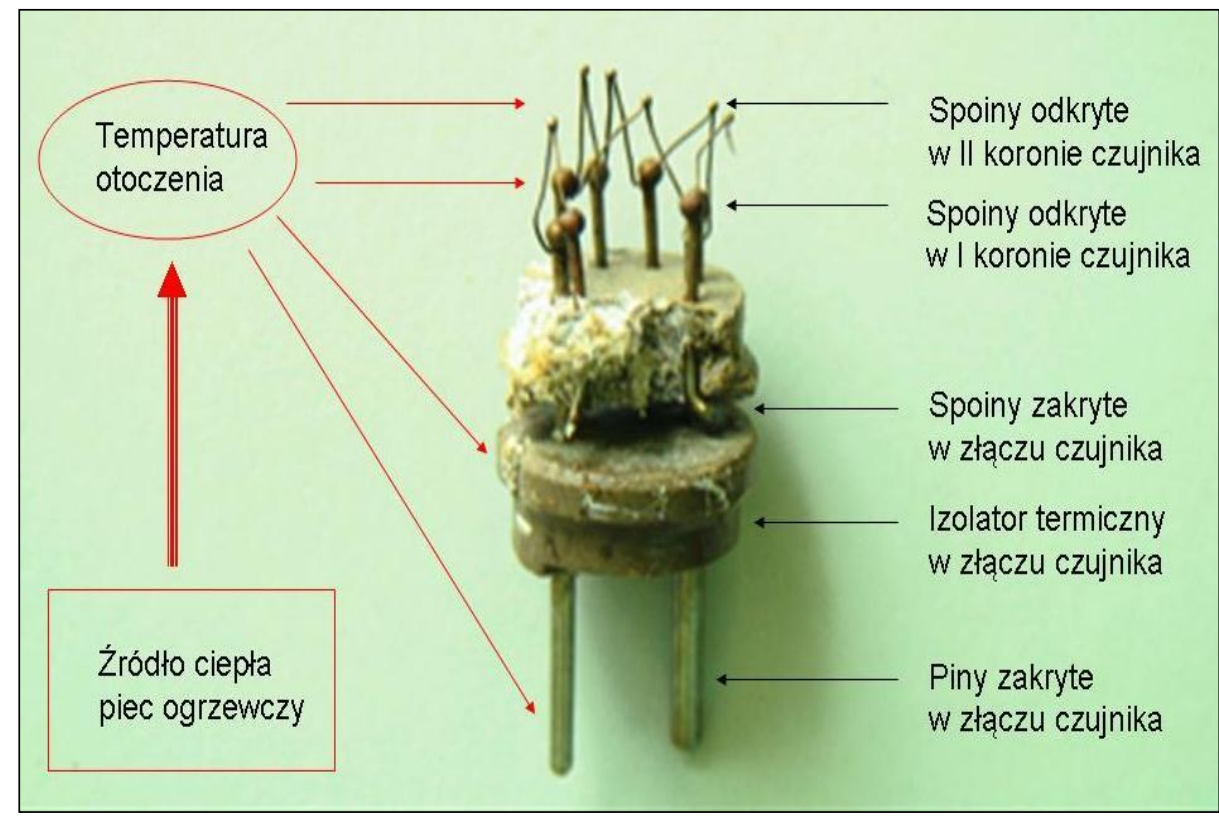

Rys. 8 Opis elementów pomiarowych i sygnałowych dla czujnika DTBG [7]

Uproszczony model matematyczny opisujący działanie termoelektrycznego czujnika pożaru DTBG, z dwoma koronami spoin odkrytych, można przedstawić przy wykorzystaniu zależności: 
Dynamic properties modeling of the thermoelectric fire sensors in the aircraft... Modelowanie dynamicznych właściwości termoelektrycznych czujników pożaru...

$$
U_{\text {DTBG }}(s)=\left\{\begin{array}{l}
K_{1}\left[\frac{1}{\tau_{\text {SO1 }} \cdot s+1} \cdot T_{\text {ОтосZ }}(s)-\frac{1}{\tau_{\text {SZ1 }} \cdot s+1} \cdot T_{\text {ZLACZA }}(s)\right]+ \\
+K_{2}\left[\frac{1}{\tau_{\text {SO2 }} \cdot s+1} \cdot T_{\text {OтосZ }}(s)-\frac{1}{\tau_{\text {SO1 }} \cdot s+1} \cdot T_{\text {OтоCZ }}(s)\right]
\end{array}\right\}
$$

gdzie:

$U_{D T B G}(s)$ - transformata operatorowa Laplace'a siły termo-elektrycznej generowanej w czujniku DTBG z podwójną koroną spoin odkrytych;

$K_{I} \quad-$ współczynnik skalowania czujnika DTBG dla I korony spoin odkrytych;

$K_{2} \quad-$ współczynnik skalowania czujnika DTBG dla II korony spoin odkrytych;

$T_{\text {отосZ }}(s)$ - transformata operatorowa Laplace'a temperatury powietrza otaczającego czujnik DTBG i oddziałującego bezpośrednio na spoiny odkryte I korony i II korony poprzez ich nagrzewanie lub chłodzenie;

$T_{Z L A C Z A}(s)$ - transformata operatorowa Laplace'a temperatury złącza elektrycznego czujnika DPS i oddziałującego pośrednio na spoiny zakryte i opóźniającego ich nagrzewanie lub chłodzenie;

$\tau_{\mathrm{SO} I} \quad-$ stała czasowa spoin odkrytych I korony;

$\tau_{\mathrm{SO} 2} \quad-$ stała czasowa spoin odkrytych II korony;

$\tau_{S Z 1} \quad-$ stała czasowa spoin zakrytych (zabudowanych w złączu).

Model ten, podobnie jak dla czujnika DPS, umożliwia m.in. badania wpływu opóźnień w nagrzewaniu i chłodzeniu poszczególnych spoin czujnika na wartość i przebieg maksymalnej siły termoelektrycznej $\mathrm{w}$ nim generowanej. $\mathrm{Z}$ uwagi na posiadanie dwóch układów spoin odkrytych (korony górnej i dolnej) wypadkowa siła termoelektryczna zależy od chwilowych rozkładów temperatury spoin I korony (charakteryzujących się dużą bezwładnością cieplną, jak w czujniku DPS) oraz spoin II korony (charakteryzujących się małą bezwładnością cieplną). Wyniki takich badań pozwalają ocenić możliwości generacji sygnału podprogowego z czujnika DTBG, powodującego fałszywe zadziałanie i uruchomienie systemu przeciwpożarowego SSP-FK przy obniżonym napięciu zasilania.

\section{Modelowanie właściwości dynamicznych czujników DPS i DTBG}

Celem badań opracowanych w ITWL modeli matematycznych działania termoelektrycznych czujników pożaru DPS i DTBG było weryfikowanie hipotezy o możliwości fałszywego zadziałania systemu SSP-FK (przy obniżonym napięciu zasilania) na skutek generacji w czujnikach DPS napięcia podprogowego podczas gwałtownych zmian temperatury otoczenia (m.in. oddziaływania mrozu, podmuchu zimnego lub gorącego powietrza). 
Przykładowy model symulacyjny (rys. 9), opracowany w pakiecie MatlabSimulink, pozwala na wprowadzanie zadanych przebiegów temperatury otoczenia (charakteryzujących warunki temperaturowe wybranej pory roku), temperatury nagrzewania (narastania temperatury po włączeniu pieca ogrzewczego KO-50 lub rozpraszaczy gazów wylotowych EWU) oraz temperatury chłodzenia (spadku temperatury wraz ze wzrostem wysokości lotu podczas realizacji lotu przez statek powietrzny).

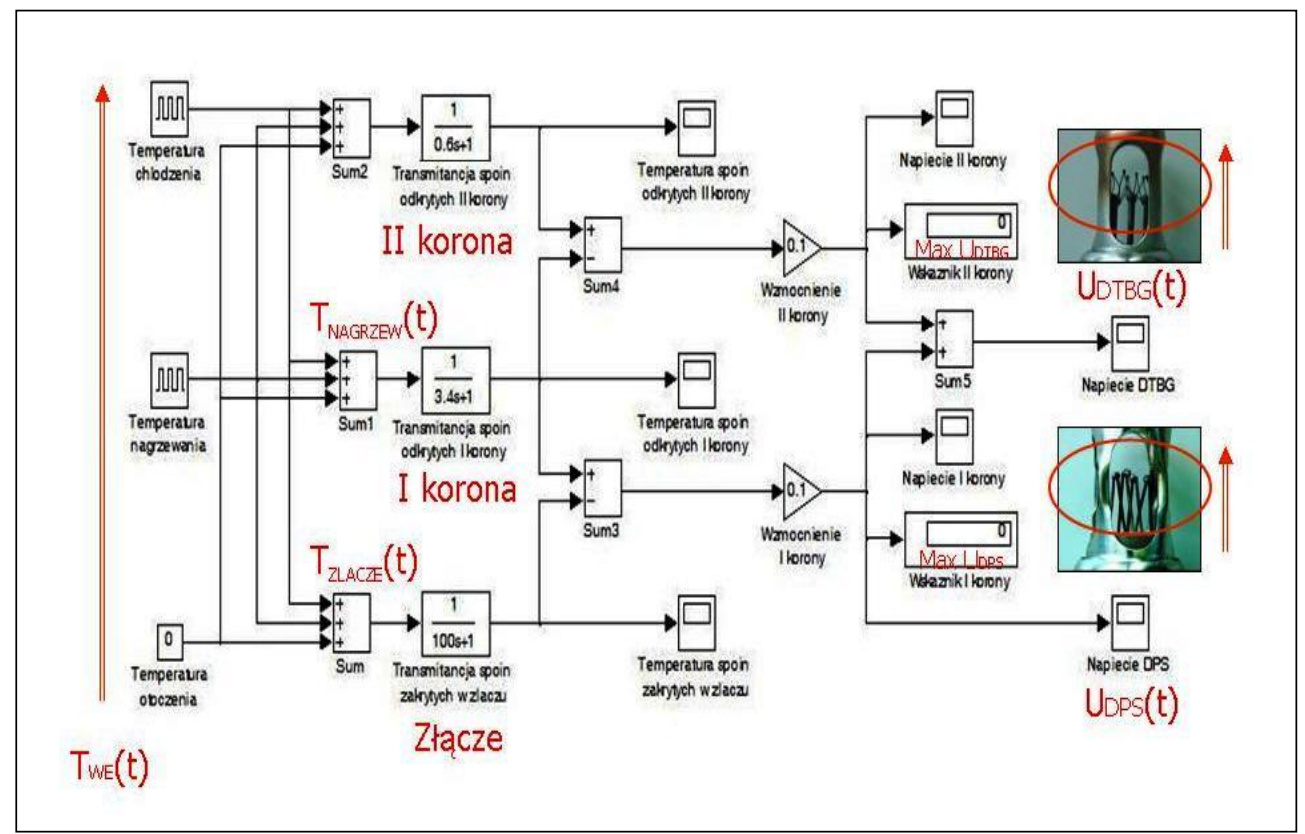

Rys. 9 Schemat modelu symulacyjnego do badań czujników DPS i DTBG [7]

Do modelowania opóźnień charakteryzujących opóźnienia w nagrzewaniu i chłodzeniu spoin odkrytych i zakrytych w złączu czujnika wykorzystano człony inercyjne I rzędu, umożliwiające wprowadzanie wybranych wartości stałych czasowych dla spoin odkrytych i zakrytych w złączu. Na podstawie wstępnych badań laboratoryjnych czujników DPS i DTBG przyjęto następujące wartości stałych czasowych: $3,4 \mathrm{~s}$ dla spoin I korony, $0,6 \mathrm{~s}$ dla spoin odkrytych II korony oraz 100 s dla spoin zakrytych w złączu.

\section{Modelowanie właściwości dynamicznych czujników typu DPS}

W trakcie badań symulacyjnych w pakiecie Matlab-Simulink stwierdzono, że dla przypadku wymuszenia temperaturowego $\mathrm{w}$ postaci skoku jednostkowego (modelowanie badania nagłego podmuchu ciepłego powietrza po włączeniu wentylatora pieca ogrzewczego KO-50 na pokładzie śmigłowca Mi-8 w warunkach 
Dynamic properties modeling of the thermoelectric fire sensors in the aircraft... Modelowanie dynamicznych właściwości termoelektrycznych czujników pożaru...

zimowych o założonym przebiegu procesu zmian temperatury powietrza otaczającego spoiny odkryte czujnika DPS (rys. 10): $-20^{\circ} \mathrm{C},+60^{\circ} \mathrm{C},-20^{\circ} \mathrm{C}$ generowana $\mathrm{W}$ czujniku siła termoelektryczna wynosi odpowiednio: $0 \mathrm{mV},+7,2 \mathrm{mV}, 0 \mathrm{mV}$.

Dodatkowo przeprowadzone badania wykazały (rys. 10.), że gwałtowne ochłodzenie powietrza otaczającego czujniki DPS poddawane ogrzewaniu $\mathrm{z}$ pieca KO-50 o założonym przebiegu zmian temperatury: $-20^{\circ} \mathrm{C},+60^{\circ} \mathrm{C}$ / $-50^{\circ} \mathrm{C} /+60^{\circ} \mathrm{C},-20^{\circ} \mathrm{C}$ wywołuje generowanie siły termoelektrycznej odpowiednio (rys. 10): $0 \mathrm{mV},+7,2 \mathrm{mV} /-2,6 \mathrm{mV} /+7,2 \mathrm{mV}, 0 \mathrm{mV}$.

Badania te wykazały, że nagłe ochłodzenie czujnika DPS nie powoduje znaczącego wzrostu siły termoelektrycznej generowanej w czujniku i nie może ono być przyczyną samoczynnego zadziałania systemu SSP-FK dla przyjętych warunków cieplnych (tj. włączenia pieca ogrzewczego KO-50).
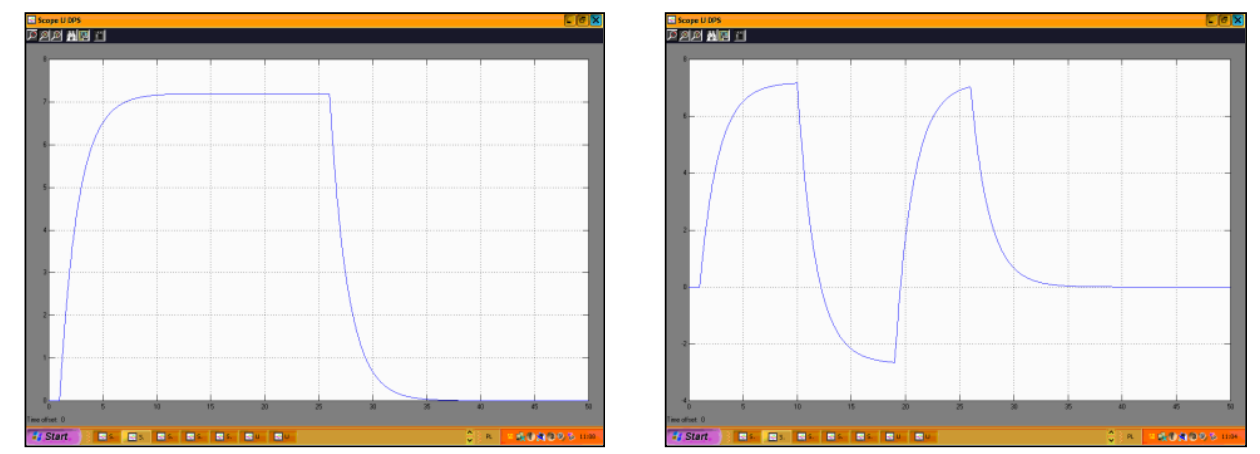

Rys. 10 Przebiegi modelowanego sygnału z czujnika DPS po nagtym ogrzaniu (po lewej) oraz przy krótkotrwałym schłodzeniu w czasie ogrzewania (po prawej) [7]

\section{Modelowanie właściwości dynamicznych czujników typu DTBG}

Podobnie jak dla badań symulacyjnych czujnika DPS stwierdzono, że dla przypadku wymuszenia temperaturowego w postaci skoku jednostkowego (modelowanie badania nagłego podmuchu ciepłego powietrza po włączeniu wentylatora pieca ogrzewczego KO-50 na pokładzie śmigłowca Mi-8w warunkach zimowych) o przebiegu procesu zmian temperatury powietrza otaczającego spoiny odkryte czujnika DTBG (rys. 11): $-20^{\circ} \mathrm{C},+60^{\circ} \mathrm{C},-20^{\circ} \mathrm{C}$ generowana w czujniku siła termoelektryczna wynosi odpowiednio: $0 \mathrm{mV},+18,2 \mathrm{mV} /+14 \mathrm{mV},-4,5 \mathrm{mV} / 0 \mathrm{mV}$.

Dodatkowo przeprowadzone badania wykazały (rys. 11), że gwałtowne ochłodzenie powietrza otaczającego spoiny odkryte czujników DTBG poddawane ogrzewaniu $\mathrm{Z}$ pieca KO-50 o założonym przebiegu zmian temperatury: $-20^{\circ} \mathrm{C},+60^{\circ} \mathrm{C} /-50^{\circ} \mathrm{C} /+60^{\circ} \mathrm{C},-20^{\circ} \mathrm{C}$ wywołuje generowanie siły termoelektrycznej odpowiednio: $0 \mathrm{mV},+18,2 \mathrm{mV} /+14 \mathrm{mV},-12 \mathrm{mV} /-5,1 \mathrm{mV},+21 \mathrm{mV} /+14 \mathrm{mV}$, $-4,5 \mathrm{mV} / 0 \mathrm{mV}$. 

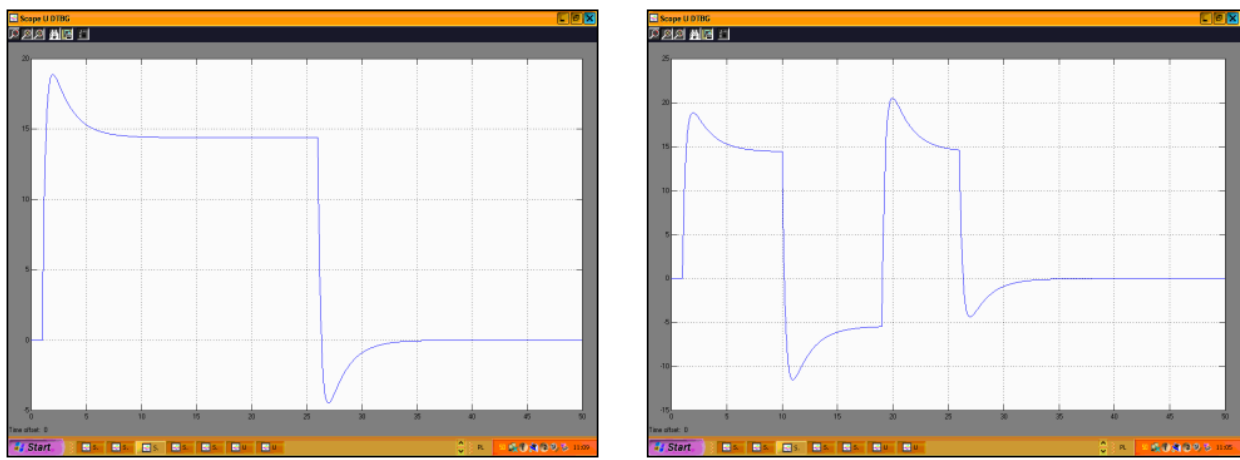

Rys. 11 Przebiegi modelowanego sygnału czujnika DTBG po nagłym ogrzaniu (po lewej) oraz przy krótkotrwałym schłodzeniu w czasie ogrzewania (po prawej) [7]

Badania te wykazały, że maksymalna wartość siły termoelektrycznej generowanej $\mathrm{z}$ jednego czujnika DTBG przekracza próg $+10 \mathrm{mV}$ (wartość minimalna wymagana dla uruchomienia układu wykrywania i sygnalizacji pożaru $\mathrm{w}$ znamionowych warunkach zasilania), z czego wynika, że czujniki typu DTBG mogą być przyczyną fałszywego zadziałania systemu SSP-FK na skutek nagłego podania ciepłego powietrza pochodzącego z pieca KO-50 (przy włączonym wentylatorze pieca) oraz jego chwilowych zmian.

\section{Weryfikacja opracowanych modeli czujników DPS i DTBG}

W celu weryfikacji wyników uzyskanych w badaniach symulacyjnych dokonano sprawdzenia wartości siły termoelektrycznej generowanej dla czujników typu DPS i DTBG umieszczonych w płomieniu zapalniczki. Następnie określono przebiegi sygnału $\mathrm{z}$ czujników DPS umieszczonych $\mathrm{w}$ komorze termicznej ITWL. Umożliwiły one ocenę możliwości generacji sygnałów podprogowych $\mathrm{w}$ czasie pracy pieca ogrzewczego KO-50.

\section{Weryfikacja modelu symulacyjnego czujników typu DPS}

Wartość maksymalna generowanego napięcia $\mathrm{z}$ termoelektrycznego czujnika pożaru DPS, umieszczonego w płomieniu zapalniczki, dochodzi do $+130 \mathrm{mV}$. Nagłe ochłodzenie spoin odkrytych czujnika (za pomocą wtrysku zmrożonego powietrza) powoduje zmniejszenie wartości siły termoelektrycznej, a nawet przyjęcie przez nią wartości ujemnej (podobnie jak w badaniach symulacyjnych). Otrzymane wyniki wykluczyły założenie, aby nagłe ochłodzenie czujnika DPS powodowało samoczynne zadziałanie systemu SSP-FK dla przyjętych warunków cieplnych (tj. podczas włączenia lub wyłączenia pieca ogrzewczego KO-50).

W czasie badań termoelektrycznych czujników pożaru DPS, wykonanych $\mathrm{w}$ komorze termicznej ITWL o nastawianej temperaturze powietrza $\mathrm{z}$ termostabilizatorem, stwierdzono, że generowały one napięcie elektryczne tylko podczas zmiany temperatury powietrza ich otaczającego (rys. 12). 
Dynamic properties modeling of the thermoelectric fire sensors in the aircraft... Modelowanie dynamicznych właściwości termoelektrycznych czujników pożaru...

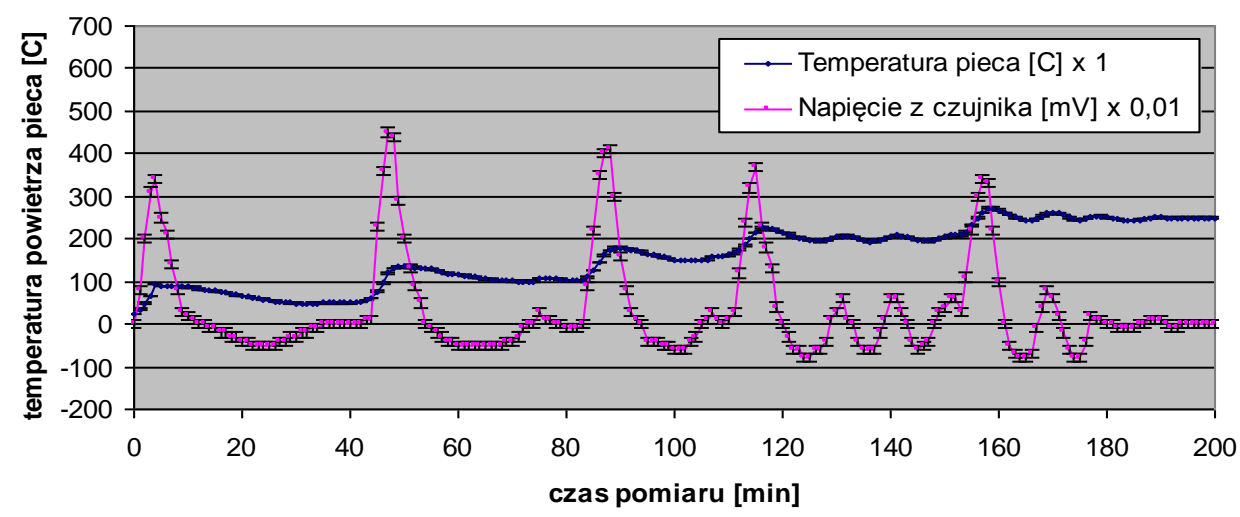

Rys. 12 Przebiegi rzeczywiste sygnatu z czujnika DPS w czasie okresowej zmiany temperatury powietrza $w$ komorze termicznej ITWL [7]

Chwilowa wartość siły termoelektrycznej otrzymywanej z czujnika DPS (rys. 13) zależała od charakteru przebiegu zmian temperatury otaczającego powietrza oraz wpływu stałych czasowych charakteryzujących opóźnienie w przewodnictwie cieplnym dla spoin odkrytych i spoin zakrytych, umieszczonych w złączu czujnika i osłoniętych materiałem izolacyjnym. Wartość współczynnika skali termoelektrycznego czujnika pożaru DPS przy zadawanych zmianach temperatury powietrza w czasie badań czujnika w komorze termicznej ITWL, oszacowano na około $10 \mathrm{mV} /{ }^{\circ} \mathrm{C} / \mathrm{s}$ [7].

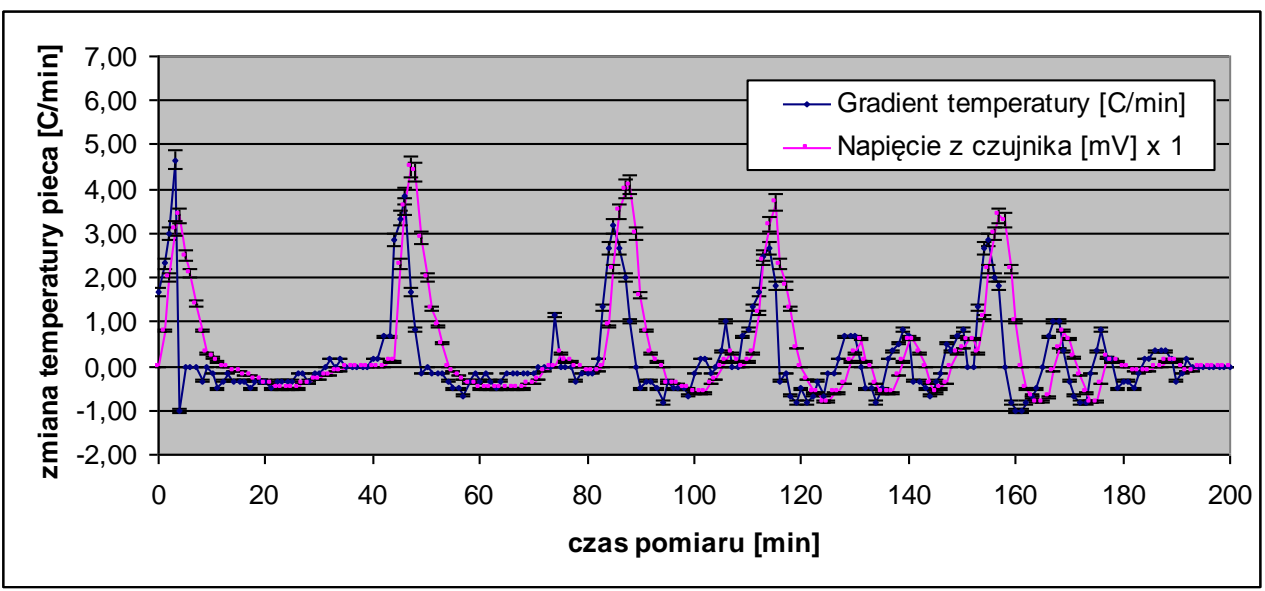

Rys. 13 Przebiegi rzeczywiste sygnału z czujnika DPS w czasie okresowej zmiany temperatury powietrza w komorze termicznej ITWL [7]

$\mathrm{Na}$ tej podstawie oszacowano wartości chwilowe siły termoelektrycznej z czujników DPS na śmigłowcu Mi-8 (które w czasie badań wykonywanych w JW Dęblin nie były wiarygodne $\mathrm{z}$ uwagi na wysoki poziom szumów). 
Stwierdzono, że w czasie włączenia do pracy pieca ogrzewczego KO-50 3 czujniki pożaru DPS, połączone w jedną grupę i zabudowane w przedziale pieca, generowały napięcie elektryczne tylko podczas zmiany temperatury powietrza otaczającego, a jego wartość maksymalna zależała od szybkości zmian temperatury powietrza i nie przekraczała $+11 \mathrm{mV}$ (rys. 14).

Otrzymane wyniki eksperymentalne wykazały, że określone w badaniach ITWL wartości napięć występujących w obwodach czujników pożaru DPS dla bloku wykonawczego SSP-FK-BI, wymagane do jego uruchomienia (o wartości minimalnej około $24 \mathrm{mV}$ i czasie trwania około $60 \div 70 \mathrm{~ms}$ dla impulsów prostokątnych), są dwukrotnie wyższe niż oszacowane wartości napięć generowanych $\mathrm{z}$ czujników pożaru z przedziału pieca ogrzewczego KO-50 na pokładzie śmigłowca Mi-8 nr $660 \mathrm{w}$ czasie jego włączenia i ciągłej pracy (impulsy dodatnie o wartości dochodzącej do $+11 \mathrm{mV}$ ).

Oceniono, że nie jest możliwe wywołanie samoczynnego zadziałania bloku SSP-FK-BI na skutek równoczesnego występowania sygnałów sterujących z termoelektrycznych czujników pożaru DPS o wartościach podprogowych rzędu $+11 \mathrm{mV}$ i chwilowych spadków napięcia w obwodzie zasilania bloku.

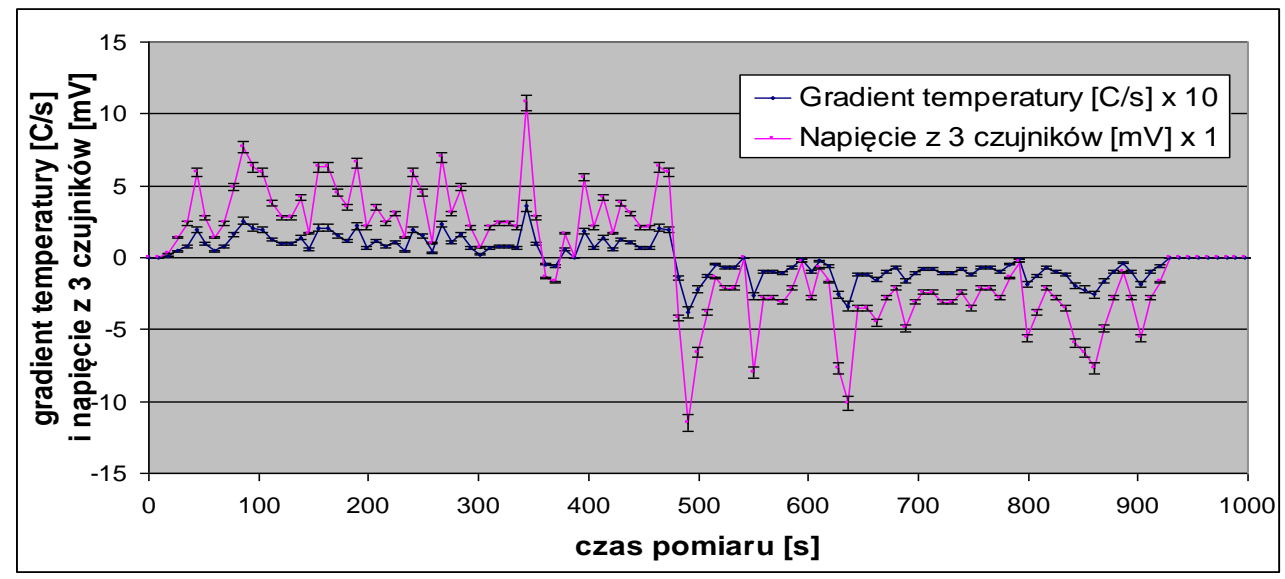

Rys. 14 Przebiegi oszacowane sygnału z grupy 3 czujników DPS w czasie zmiany temperatury powietrza w obszarze pieca KO-50 na śmigłowcu Mi-8 [7]

\section{Weryfikacja modelu symulacyjnego czujników typu DTBG}

Wartość maksymalna generowanego napięcia $\mathrm{z}$ czujnika pożaru DTBG, umieszczonego w płomieniu zapalniczki, dochodzi do $+270 \mathrm{mV}$. Podobnie jak dla czujnika DPS, nagłe ochłodzenie spoin zewnętrznych czujnika DTBG powoduje zmniejszenie wartości siły termoelektrycznej, a nawet przyjęcie przez nią wartości ujemnej (jak w badaniach symulacyjnych). Wynika stąd, że czujniki DTBG są dwa razy „wrażliwsze” w stosunku do czujników DPS. Dla warunków temperaturowych, panujących na pokładzie śmigłowca Mi-8 nr $660 \mathrm{w}$ przedziale pieca KO-50 w czasie jego włączenia i ciągłej pracy, oszacowane maksymalne 
Dynamic properties modeling of the thermoelectric fire sensors in the aircraft... Modelowanie dynamicznych właściwości termoelektrycznych czujników pożaru...

wartości napięć generowanych $\mathrm{z}$ czujników DTBG dochodzą do $+22 \mathrm{mV}$ $\mathrm{i}$ stanowią wartości podprogowe $\mathrm{w}$ porównaniu $\mathrm{z}$ napięciami wymaganymi do uruchomienia i sygnalizacji bloku wykonawczego SSP-FK-BI (o wartości minimalnej około $+24 \mathrm{mV}$ i czasie trwania około $60 \div 70 \mathrm{~ms}$ dla impulsów prostokątnych).

Oceniono zatem, że jest możliwe wywołanie samoczynnego zadziałania bloku wykonawczego SSP-FK-BI na skutek równoczesnego występowania sygnałów sterujących $\mathrm{z}$ termoelektrycznych czujników pożaru DTBG o wartościach podprogowych rzędu $+22 \mathrm{mV}$ i chwilowych spadków napięcia w obwodzie zasilania bloku. Otrzymane wyniki potwierdziły więc hipotezę, że czujniki typu DTBG mogą być przyczyną fałszywego zadziałania systemu SSP-FK na skutek nagłego nagrzania spoin przez ciepłe powietrze dla przyjętych warunków cieplnych (tj. włączenia lub wyłączenia pieca ogrzewczego KO-50) z uwagi na ich dużą czułość.

Właściwość ta thumaczy zrealizowaną już w Siłach Zbrojnych RP wymianę czujników typu DTBG na czujniki typu DPS w systemach przeciwpożarowych SSP-FK, wykorzystujących bloki wykonawcze typu SSP-FK-BI.

\section{Podsumowanie}

Wykonane w ITWL badania symulacyjne i eksperymentalne opracowanych modeli matematycznych systemu przeciwpożarowego SSP-FK w zakresie termoelektrycznych czujników pożaru DPS i DTBG umożliwiają określenie zarówno warunków powstawania, jak i wartości chwilowych parametrów sygnału napięciowego otrzymywanego z czujnika pożaru dla czynników temperaturowych wywołujących samoczynne zadziałanie systemu SSP-FK (m.in. kształt, wartość maksymalna i czas trwania sygnału).

Zaproponowane metody badań symulacyjnych, opracowane w ITWL, wspomagają proces diagnozowania systemów przeciwpożarowych typu SSP-FK w zakresie określania przyczyn ich samoczynnego zadziałania. Stanowią narzędzie badawcze, przewidziane do zastosowania przy określaniu przyczyn ich nieprawidłowej pracy w ramach komisji badania wypadków lotniczych. Wyniki wykonanych symulacji komputerowych zostały wykorzystane do diagnostyki systemu przeciwpożarowego SSP-FK w trakcie badania wybranych przypadków jego samoczynnego zadziałania (m.in. ekspertyza realizowana w ITWL w latach 2014 $\div 2015$ ).

\section{Literatura}

[1] Instrukcja MON: Śmigłowiec Mi-8/Opis osprzętu, Lot. nr 1236/69, Warszawa, 1971.

[2] Instrukcja MON: Śmigłowiec Mi-8/Eksploatacja i obsługa osprzętu, Lot. nr 1263/69, Poznań, 1970.

[3] Materiały analityczne ITWL: Zestawienie przypadków fałszywego zadziałania instalacji przeciwpożarowej SSP-FK w latach 2010-2014. System Informatyczny SI SAMANTA. 
[4] Michalak S., Szelmanowski A., Skoczylas D.: Badanie przyczyn fałszywego zadziaływania instalacji przeciwpożarowych, Sprawozdanie z pracy, BT ITWL nr 10514/I, Warszawa, 1993.

[5] Norma Obronna MON: Wojskowe statki powietrzne/Pokładowe układy zasilania elektrycznego/Podstawowe parametry, wymagania i badania, NO-15-A200:2007.

[6] Szelmanowski A. i inni: Badania przyczyn nieprawidłowego działania bloków wzmacniaczy instalacji przeciwpożarowej SSP-FK-BI, Protokół z badań, BT ITWL nr 5984/50, Warszawa, 2010.

[7] Szelmanowski A. i inni: Badania przyczyn nieprawidłowego działania bloków wzmacniaczy instalacji przeciwpożarowej SSP-FK-BI, Protokół z badań, BT ITWL nr 5984/50, Warszawa, 2015.

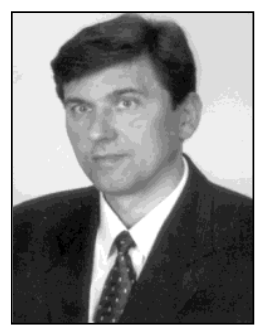

Dr hab. inz. Szelmanowski Andrzej, Instytut Techniczny Wojsk Lotniczych, Warszawa, Profesor nadzwyczajny $w$ Zaktadzie Awioniki, specjalizacja: komputerowo zintegrowane systemy awioniczne, lotnicze nahelmowe systemy celownicze, lotnicze systemy nawigacyjne, systemy automatycznego sterowania lotem, lotnicze systemy przeciwpożarowe. Autor kilkudziesięciu prac $w$ tej dziedzinie (Udzial 30\%).

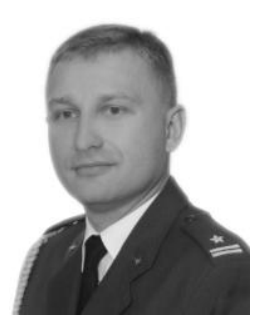

Dr hab. inz. Zieja Mariusz, Instytut Techniczny Wojsk Lotniczych, Warszawa, Kierownik Pracowni w Zaktadzie Informatycznego Wsparcia Logistyki, specjalizacja: osprzęt samolotów $i$ śmigłowców, systemy informatycznej analizy niezawodności techniki lotniczej, systemy szacowania ryzyka i zapewnienia bezpieczeństwa lotów. Autor kilkudziesięciu prac w tej dziedzinie (Udzial 30\%).

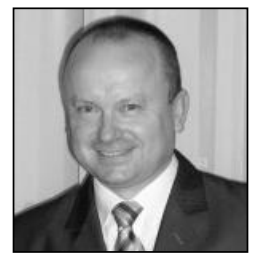

Mgr in.. Glyda Krzysztof, Instytut Techniczny Wojsk Lotniczych, Warszawa, Specjalista $w$ Zakładzie Informatycznego Wsparcia Logistyki, specjalizacja: systemy nahetmowego wyświetlania parametrów lotu i celowania, lotnicze systemy przeciwpożarowe, lotnicze komputerowe systemy rejestrujace i pomiarowe. Autor kilku prac w tej dziedzinie (Udzial 40\%). 